\title{
THE POTENTIAL OF WASTEWATER REUSE FOR AGRICULTURAL IRRIGATION IN LIBYA: TOBRUK AS A CASE STUDY
}

\author{
ABDULLA A. ${ }^{1, *}$ \\ OUKI S. ${ }^{2}$
}

\author{
${ }^{1}$ Technical Affairs Office, Housing and Utilities of Tobruk \\ Ministry of Housing and Utilities, Libya \\ ${ }^{2}$ University of Surrey, Centre of Environmental and Health Engineering \\ Guildford, Surrey, GU2 7XH, UK.
}

Received: 29/09/2014

Accepted: $12 / 03 / 2015$

Available online: $28 / 04 / 2015$ *to whom all correspondence should be addressed: e-mail: vision_76@hotmail.com

\begin{abstract}
The aim of this paper is to highlight the way towards the exploitation of treated wastewater for food crops production in order to cope with the acute water scarcity and its hazardous consequences. Reclaimed water reuse has not been practiced in Tobruk, and hence, lack of relevant data and information was the major difficulty in carrying out this research. The existing sewage treatment plant in Tobruk city produces about 7,000 cubic meters per day of suitable effluent for agricultural irrigation and safe discharge. This proportion is worth twice as much as the water being currently used for irrigation. Therefore, with proper planning and management, treated wastewater reuse schemes, in addition to their economical and environmental benefits, can be an efficient mechanism to cope with water shortage and reducing the high burden placed on the desalination plant. Wastewater reuse is considered as a reliable, secure, and drought-resistant water source. Owing to the lack of disinfection processes and routinely monitoring data, there is uncertainty concerning the microbiological safety and quality of the treated effluent. Public perception might be the major challenge facing the planning for a reuse scheme as $51 \%$ of the population of Tobruk have shown their reluctance to consume food crops irrigated with treated wastewater. Nonetheless, public attitudes can be fostered by awareness through the media as some people, when the issue was discussed, have shown a positive response. In fact their main concerns were related to public health safety and potential negative environmental impacts which can be addressed through good planning and prudent management.
\end{abstract}

Keywords: wastewater reuse, water scarcity, agricultural irrigation, Tobruk, Libya, Mediterranean

\section{Introduction}

Water scarcity represents a major problem that is faced by Tobruk. Increasing population, rapid urban expansion, and rising demand for food place much pressure on diminished water resources availability. Tobruk region is in urgent need of viable water resources to cope with water scarcity which threatens its development and welfare.

Depletion of natural water resources and increasing concerns over the economic and environmental issues of seawater desalination (the major source of water in the city) make the $7,000 \mathrm{~m}^{3}$ of treated wastewater discharged into the sea every day too valuable to waste.

The reuse of wastewater for irrigation is not a novel idea; it was practised thousands of years ago by the Minoan Civilization in Crete, Greece (Angelakis et al., 1999, 2003 cited in Metcalf and Eddy, 2007, p. 39).

Abdulla A. and Ouki S. (2015), The potential of wastewater reuse for agricultural irrigation in Libya: Tobruk as a case study, Global NEST Journal, 17(2), 357-369. 
In modern times, India has been practicing wastewater reuse for irrigation for nearly hundred years (Shende et al., 1988 cited in Mara, 2003). Currently, in the United States of America, more than $1.7 \mathrm{Mm}^{3}$ of wastewaters are recycled each day in Florida and California mainly for food crops irrigation and landscaping. And, Mexico City, the second largest metropolis in the world, reached zero effluent discharge by using all its wastewater for irrigation (Duron, 1988 cited in Mara, 2003). In Saudi Arabia, the very arid country, reclaimed water reuse is being now considered as a key strategy for the conservation of water (Al-Jasser, 2010).

In the MENA (The Middle East and North Africa) region to which Tobruk, Libya belongs, the reuse of treated effluents is well known for having a potentially important role to alleviate water scarcity problems in the region (Abu Madi, 2004). MENA's pioneer countries in agricultural water reuse are Israel, Jordan (Figure 1) and Tunisia, satisfying 20, 10 and $1.3 \%$ of their total water demand, respectively (Abu Madi, 2004; Lazarova and Bahri, 2005).

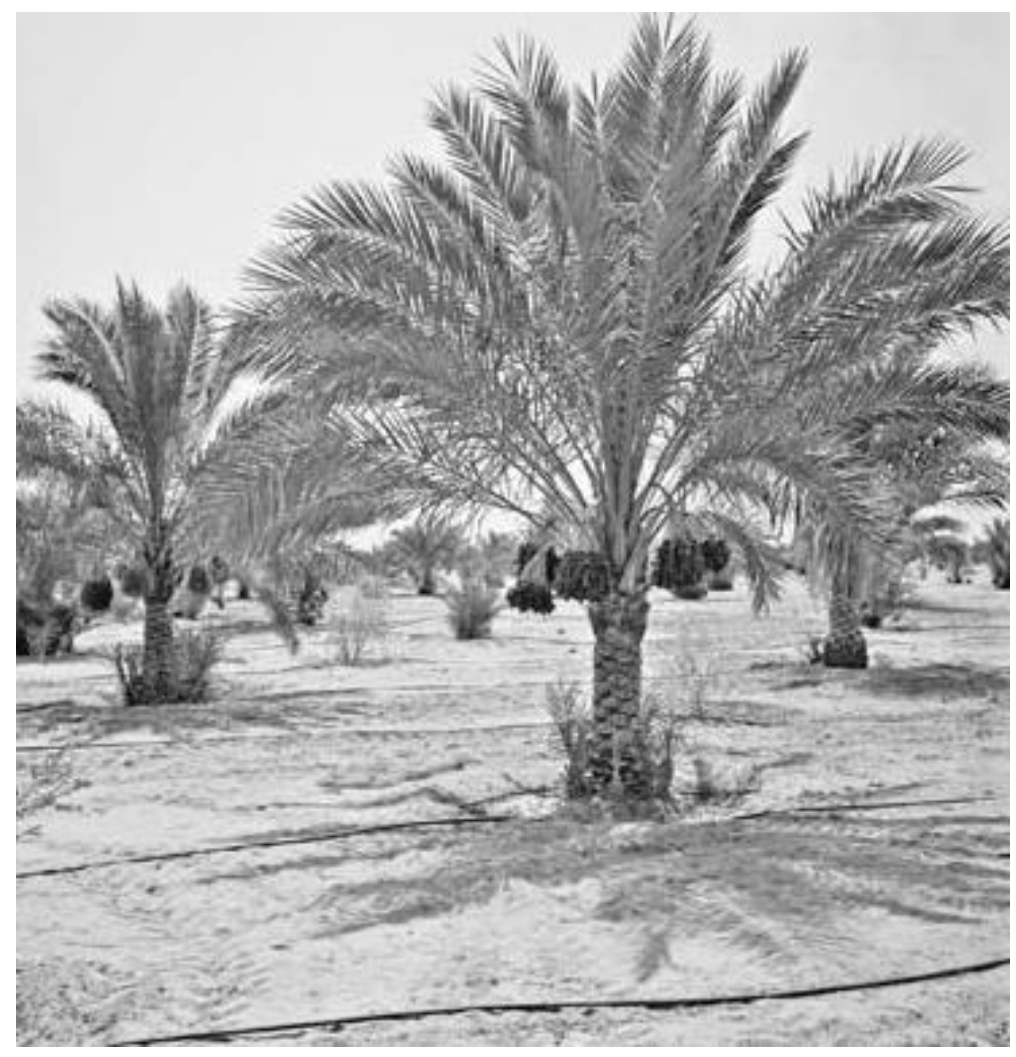

Figure 1. Reclaimed water used for drip irrigation of date palms in Aqaba, Jordan (Source; Metcalf and Eddy, 2007).

Facts and figures, supported by empirical evidence, in relevant works that had been done previously in North Africa and the Middle East provide a powerful incentive for water reuse in Tobruk to be investigated. Agricultural water reuse has not been practised in Tobruk, and therefore the main purpose of this paper is to examine the potential of reclaimed water to provide the region with an additional water resource.

\section{Methods}

\subsection{Study Area}

Tobruk is an urban area located in the north-east of Libya on the Mediterranean Sea. It is characterised by arid climate with hot dry summers and moderate rainy winters. It has a population of about 100,000 
and is famous for having an excellent natural harbour, beautiful beaches, and historical sites which give the city its commercial and touristic importance.

Over the past ten to fifteen years the city has seen quick economic growth, extensive urban expansion, as well as increasing rural to urban area migration. Hence, an enormous pressure has been exerted on water, housing and utilities supply.

\subsection{Data Collection}

The geographical, climatic and population data was obtained from Abdulla (2010). The data describing the agricultural activity was collected from field studies, personal interviews with local farmers and satellite images provided by Google Earth. Information related to wastewater generation, collection and treatment were obtained from the head and staff of Tobruk's sewage treatment plant and pumping stations.

\subsection{Water Situation in Tobruk}

Given that the annual average of water availability for Libyans is $380 \mathrm{~m}^{3}$ per capita per year (Alghariani, 2008) indicates that Tobruk is a severe water-stressed region (Pereira et al., 2009). However, an unpublished field study conducted on water resources in Tobruk (Tahani et al., 2012) shows that the annual average of water consumption in Tobruk is much less than that (29-36 $\mathrm{m}^{3} / \mathrm{c} / \mathrm{year}$ ) which means that the water situation in the region can be much worse than arbitrary statistics and figures would tell.

\subsubsection{Surface water}

With the exception of rainwater ponds which are formed in rural areas, only during rainy periods in winters, there are no surface water resources at all within the Tobruk's area. (Abdulla, 2010) states that natural rainwater ponds, if rainwater harvesting practiced on large-scale, can provide the city with significant amounts of good quality water that can be used for irrigation and /or potable purposes after minimal treatment.

\subsubsection{Groundwater resources}

Meagre annual rainfall (Abdulla, 2010), over-pumping from Tobruk's coastal aquifers and seawater encroachment have led to severe water level decline and quality deterioration. Physicochemical parameters (Table 1) of groundwater samples collected from coastal wells demonstrate that groundwater resources in Tobruk are of high salinities. Moreover, one sample shows high level of nitrate and the presence of microbial and chemical contaminants. According to Younger (2007), based on water-quality issues, Tobruk's groundwater resources are unsuitable for irrigation.

Table 1. Physicochemical parameters of groundwater resources in Tobruk

\begin{tabular}{cccc}
\hline Parameter & \multicolumn{3}{c}{ Groundwater well area } \\
\cline { 2 - 4 } & $\begin{array}{c}\text { City centre } \\
\text { Well }(1)^{\mathrm{a}}\end{array}$ & $\begin{array}{c}\text { City centre } \\
\text { Well }(2)^{\mathrm{b}}\end{array}$ & Suburb \\
\hline Well depth in $(\mathrm{m})$ & - & 70 & 118 \\
Distance from sea in $(\mathrm{m})$ & 400 & 2000 & 5600 \\
$\mathrm{pH}$ & 7.4 & 7.6 & 8 \\
Total hardness $\left(\mathrm{mg} \mathrm{l}^{-1}\right)$ & 228 & - & 126 \\
Elec. Conductivity $\left(\mathrm{\mu S} \mathrm{cm}^{-1}\right)$ & 2542 & $>1000$ & $>2000$ \\
Nitrate $\left(\mathrm{mg} \mathrm{l}^{-1}\right)$ & 40 & - & - \\
Microbial \& chemical contaminants & positive & - & - \\
\hline
\end{tabular}

\subsubsection{Desalinated water}

The $40,000 \mathrm{~m}^{3} \mathrm{~d}^{-1}$ desalinated water produced, albeit disrupted, by Tobruk's seawater desalination plant is almost the sole resource of water for the city. This quantity of water is used for all purposes, including industrial processes and irrigation. The plant uses MED-TVC technology (Multi-effect Desalination-Thermo 
Vapour Compressor) and operated by heavy oil which, in fact, does not favour the sustainable development in terms of cost and environmental impacts.

\subsection{The Need for Alternative Water Resource}

Based on facts and figures mentioned previously, there is an urgent need for alternative water resources to be found to cope with water scarcity and maintain food security in Tobruk. The main objective of this paper is to draw decision makers' attention toward wastewater reuse as a sustainable source of water to mitigate the large burden placed on Tobruk's desalination plant.

The reason why treated wastewater is not used in Tobruk is probably due to the absence of long-term government policies, lack of knowledge and socio-cultural aspects. Nonetheless, we strongly believe that it is time, for all, i.e. people, farmers and government, to start utilising reclaimed wastewater for agricultural irrigation to achieve sustainable development, saving water and secure increased need for food.

\subsection{Agricultural Production in Tobruk}

Although Tobruk's arable land area is estimated at 945 ha, the cultivated land area, however, is only 420 ha. This is not surprising as water scarcity has led to a significant decline in trend toward agricultural production. Instead of attempting to redress the problem, considerable areas of arable lands are currently devoted for housing estate.

A field study and visits have shown that the quantity of water used for agricultural production is about $3,500 \mathrm{~m}^{3} \mathrm{~d}^{-1}$. Given that, desalinated water is the only resource of water for the region, then agriculture consumes $9 \%$ of Tobruk desalination plant's yield.

The most cultivated vegetables, for daily consumption, are tomato, pepper, lettuce, onion, parsley, marrow in addition to some seasonal fruits, primarily grapes.

Surging population has undoubtedly led to increasing demand from the city on the major water resource (Tobruk's desalination plant) and hence, exacerbating the gap between water escalating demand and water availability. Increasing population has also resulted in a sharp increase in food demand which could not be met by the city, in particular after the local Water Authority has stopped water supply to many farms. Consequently, local agricultural production has been adversely affected, and shortage in food requirements is now being compensated by importing from Egypt and other local markets. Local farmers are concerned over the situation and describing it as dangerous.

Water demand burdens water-stressed societies and thus population will most likely resort-without taking into account quality and health considerations-to any available water to cope with the problem.

\section{Wastewater treatment and collection}

\subsection{Wastewater Collection}

Domestic sewage produced from the urban population in Tobruk is collected by sewerage system into three pumping stations from which sewage is then pumped to the sewage treatment plant (STP). Nevertheless, about $40-45 \%$ of households are not connected to the municipal sewers and they dispose of their domestic wastewater using cesspits. Although, this way of domestic wastewater disposal has been practiced for so many years, yet, no action has been taken by concerned governmental institutions (e.g. Water Authority and Environment Protection Department).

It is worth mentioning that sanitation and sewerage systems in Tobruk is deteriorating and raw sewage overflows frequently occur causing nuisance and exposing public health and the environment to danger. Poor sewerage system, in some areas, allows huge amounts of sediment (e.g. fine particles, sands and silt) entering, through cracks and improperly covered manholes, into sewers. This results in major operational problems at pumping stations and the STP. 


\subsection{Wastewater Treatment}

Wastewater collected from the city is pumped to the STP, treated and discharged, by gravity, into a nearby beach. Tobruk's sewage treatment plant (Figure 2) is a conventional plant designed to treat up to 20,000 $\mathrm{m}^{3} \mathrm{~d}^{-1}$ of municipal wastewater, primarily domestic sewage, and thus it consists of combination of physical and biological processes; screening, aeration, secondary sedimentation and sludge thickening. No chemical processes are included, not even chlorination.

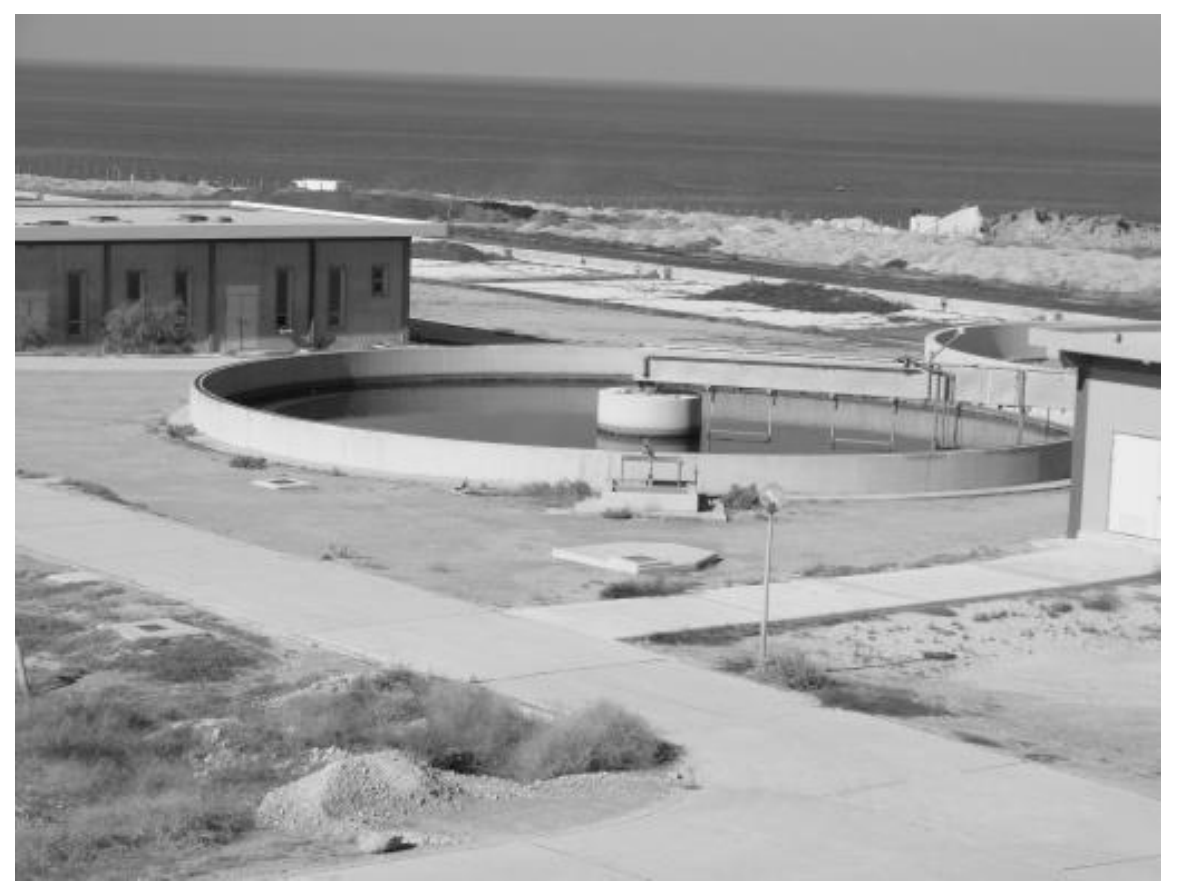

Figure 2. Sewage treatment plant, Tobruk (Photo by; Abdulla, 2012)

The plant design capacity was based on the assumption that the average domestic water consumption is $0.2 \mathrm{~m}^{3}$ per capita per day and therefore, the daily influent was estimated as:

Daily influent $=$ population $\mathrm{x}$ daily water consumption per capita

\subsection{Effluent characteristics}

Two sets of the physico-chemical, organic and microbial characteristics of the influent and the final effluent from Tobruk's STP are presented in Table 2. Due to the lack of microbiological analyses at the STP's laboratories, samples from the treated effluent were collected and sent to a private accredited laboratory. Representative samples of the final effluent for BOD and SS over a period of six months are shown graphically in Figure 3.

\section{An overview of the quality of the reclamed water for irrigation}

Water quality is, undoubtedly, the most significant factor in water reuse schemes since the protection of public health is perceived as a high priority. Besides this, a successful reuse programme is to take into account the potential environmental impacts (Abu Madi, 2004) and economic feasibility (Abu-Rizaiza, 1999 cited in Abu Madi, 2004).

In order to protect public health and minimise the negative impacts of reclaimed wastewater on soil and water resources, regulations and guidelines concerning water quality for the agricultural irrigation have been developed. Every effort was made to obtain the Libyan standards for irrigation with reclaimed wastewater, but to no avail. It seems that Libya has yet to set its national standards, and WHO guidelines have been adopted in the country since the beginning of 1980s. Therefore, WHO and other widely used 
guidelines have been adopted in this paper for the evaluation of the suitability of wastewater treated by Tobruk's sewage treatment plant for the irrigation of food crops. The suitability of a treated effluent is determined mainly by pathogens, salinity, specific ion toxicity, trace elements and nutrients (Lazarova and Bahri, 2005).

Table 2 Characteristics of Tobruk STP's Influent and Effluent

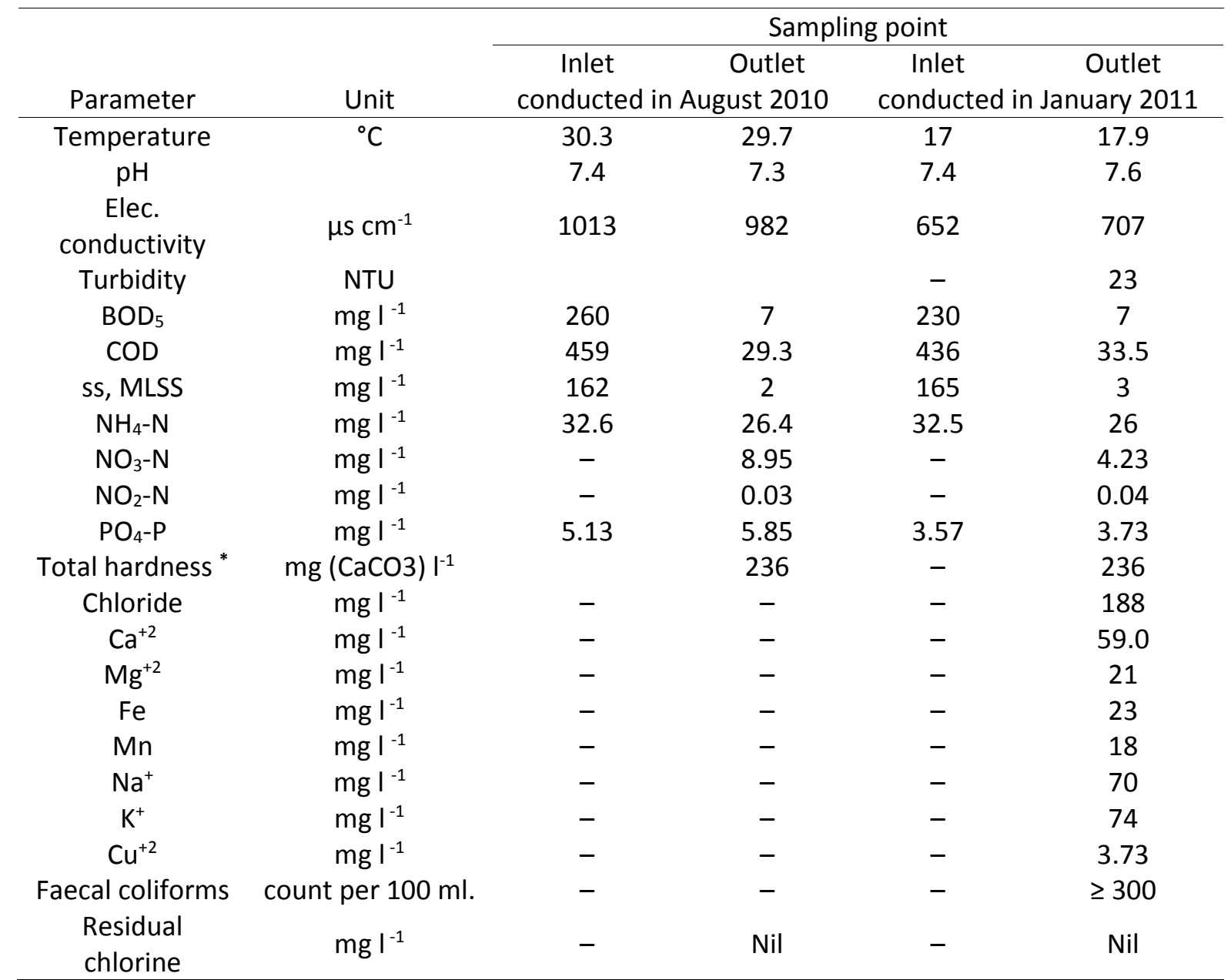

Source: By permission from Tobruk's Sewage Treatment Plant. Sampling conducted in August 2010 and January 2011. * Abdelbassit Alkarbal, accredited water analyses laboratories.

The suitability of water for irrigation is based primarily on salinity (Pereira et al., 2009; Metcalf and Eddy, 2003). Salinity is an issue for arable agriculture because: (i) it impedes the uptake of water by plants; and (ii) it can affect the soil structure, resulting in reduced or impeded infiltration (Younger, 2007). Salinity is usually measured as electrical conductivity in $\mu \mathrm{s} \mathrm{cm}^{-1}$.

Besides salinity, sodium adsorption ratio (SAR) is also an important quality parameter when domestic wastewater effluent is used for irrigation because of its sodium content. Sodium is required in limited amount for most plant growth, however it can adversely affect plant growth at high concentrations. For crop irrigation, the acceptable SAR varies according to the crop type and chemistry of the soil (Smith and Scott, 2005), but severe damage might occur when SAR exceeds 9 (Lazarova and Bahri, 2005).

The SAR, which is dimensionless index, is defined by:

$\mathrm{SAR}=\mathrm{Na}^{+} /\left[0.5\left(\mathrm{Ca}^{+2}+\mathrm{Mg}^{+2}\right]^{0.5}\right.$

Where $\mathrm{Ca}^{+}, \mathrm{Mg}^{2+}$ and $\mathrm{Na}^{+}$concentrations are expressed in milli-equivalents per litre.

Converting the concentration of $\mathrm{Ca}^{+}, \mathrm{Mg}^{2+}$ and $\mathrm{Na}^{+}$given in Table 2 to $\mathrm{mEq}^{-1}$ by multiplying by 0.050 , 0.082 and 0.044 for calcium, magnesium and sodium, respectively yields: 


$$
\begin{aligned}
& \mathrm{Ca}^{+}=59 \times 0.050=2.95 \mathrm{mEq} \mathrm{I}^{-1} \\
& \mathrm{Mg}^{2+}=21 \times 0.082=1.70 \mathrm{mEq} \mathrm{l} \\
& \mathrm{Na}^{+}=70 \times 0.044=3.00 \mathrm{mEq} \mathrm{l}
\end{aligned}
$$

The term specific ion toxicity refers to the decline of crop growth as result of excessive concentration of three major chemicals (sodium, chloride and boron) in reclaimed water used for irrigation (Metcalf and Eddy, 2003).

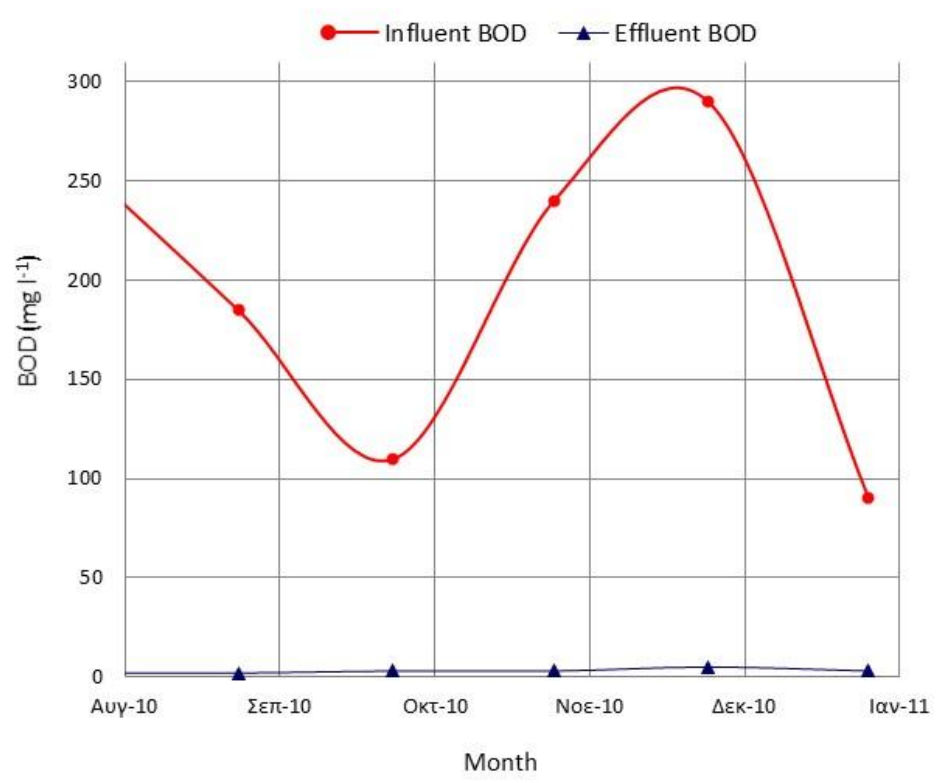

(a) BOD performance

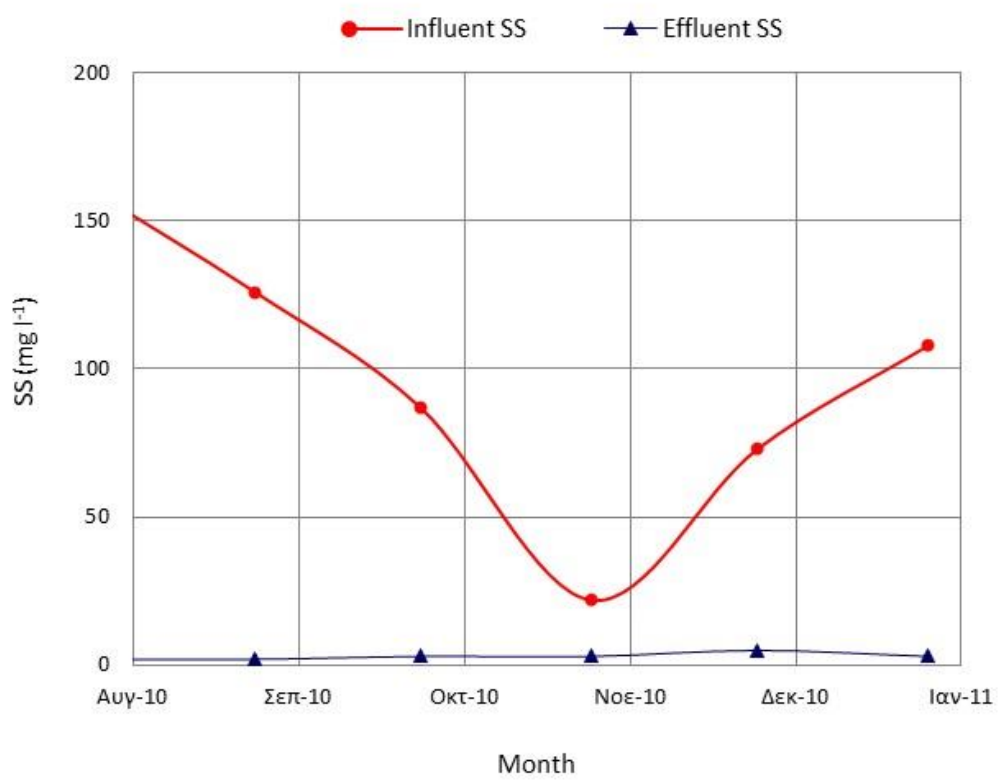

(b) SS performance

Figure 3. BOD \& SS performance data for Tobruk's STP over a period of six months, August 2010 to January 2011 
Boron is required as a micronutrient for good plant growth (Smith and Scott, 2005; Metcalf and Eddy, 2007), however, in terms of toxicity effects, boron can become toxic to most plants when present at levels that exceed crops needs (Younger, 2007; Metcalf and Eddy, 2007). Crops tolerance to boron depends on climatic, soil conditions and the crop itself. In general, some edible crops (e.g. tomato and parsley) can tolerate boron levels up to $6.0 \mathrm{mg}$ I (Lazarova and Bahri, 2005, p. 136).

Lazarova and Bahri $(2005$, p. 49) state that trace elements should receive attention in the analysis of reclaimed municipal wastewater used for regular irrigation, especially if contamination with industrial effluents is suspected. Trace elements and heavy metals can occur in reclaimed water. They may accumulate in irrigated crops and create hazards to these crops and humans or animals feeding on them.

\section{The social and cultural aspects of wastewater reuse}

Because of its origin, public attitude toward the use of reclaimed water for irrigation of food crops plays a crucial role for the success of wastewater reuse programmes (Kretschmer, nd; Metcalf and Eddy, 2007; Abu Madi, 2004). Considering this claim, a survey of people opinions and perceptions had to be conducted on Tobruk's society. The study was aimed at permanent resident citizens who are +18 years-old, with no limits to gender or education level.

\section{Results and discussions}

\subsection{Quantity of Treated Wastewater}

Based on design criteria mentioned in (section 3.2), solving Eq. (1) yields $20,000 \mathrm{~m}^{3}$ of the STP's daily influent. However, the plant's actual influent averages about $7,000 \mathrm{~m}^{3} \mathrm{~d}^{-1}$. This is because nearly $40-45 \%$ of households in the city are not connected to the municipal sewers, and also due to the uncertainty regarding the domestic water consumption per capita which was overestimated. Insufficient influent creates operational problems at the sewage treatment plant, but they are beyond the scope of this paper.

In terms of water resources management, the treated effluent is worth around $17 \%$ of the water produced by the major water resource (seawater desalination plant) in Tobruk area. With proper planning and management of water reuse scheme, this proportion of reclaimed water can considerably alleviate the pressure posed on the desalination plant, and consequently preserve high quality water for potable purposes, reduce cost and protect the environment from the hazardous emissions resulting from the heavy oil combustion needed for the plant operation.

The issues that should receive great attention are the leaking sewers and the method by which, a significant proportion of the unsewered households dispose their domestic wastewater, i.e. empty their wastewater into permeable cesspits. In addition to the public health risk associated with such practices, in some urban arid regions a significant amount of groundwater recharge may be indirect recharge from leaking sewers or pit latrines (Lerner, 1997 cited in Misstear et al., 2006).

\subsection{Quality and suitability of the treated effluent for irrigation}

\subsubsection{Pathogenic microorganisms}

Although greater attention has to be placed on the microbiological parameters, only faecal coliforms bacteria were detected in a treated effluent sample. This is due to the lack of water laboratories specialised in water and wastewater microbiology in the region, and this seems to hinder researches which require high accuracy needed for planning purposes. The microbiological analysis has shown that the effluent faecal coliforms concentration is $\geq 300$ per $100 \mathrm{ml}$. In terms of public health protection, this concentration of faecal coliforms meets the $1989 \mathrm{WHO}$ guidelines standards $\left(<1000 \mathrm{FC} 100 \mathrm{ml}^{-1}\right)$ for crops eaten raw. However, this does not necessarily mean that the effluent is microbiologically safe since there are other important parameters (e.g. viruses, protozoa, and helminths) which could not be detected for the reason previously mentioned. According to Shuval and Fattal (1996), the ideal wastewater treatment process required for reuse purposes, should be particularly effective in removing helminths, albeit less 
efficient in removing bacteria and viruses. Based on this assumption and the fact that the Tobruk's sewage treatment plant does not include any disinfection processes, we expect that treated effluent contains other pathogenic microorganism (e.g. helminths) than faecal coliforms, despite they were not determined. Therefore, final effluent needs adequate disinfection to reduce pathogen concentrations to acceptable levels before re-use in agriculture.

Although, disinfection can be carried out by using either chlorine or ozone or UV radiation, the latter is favoured over the former two means as it is rapid and does not add to the toxicity of wastewater (EPA Victoria 2002) and, in addition to their cost effectiveness, UV systems require no specific safety control or equipment (Lazarova and Bahri, 2005). Use of chlorination, in conjunction with UV, represents the best available practice where bacterial re-growth is a considered a risk (EPA Victoria 2002)

Moreover, drip irrigation is particularly recommended as it has the advantage over the other methods of wastewater application in that it is extremely economical with irrigation water (Mara, 2003) and also its hygienic advantages make it attractive as a safe method of wastewater irrigation of unrestricted irrigation, even if the microbial quality of the effluent is less than that of the strictest standards (Shuval and Fattal, 1996).

In addition to its conformity with the international and regional guidelines for treated wastewater reuse for agriculture, the effluent (Figure 4), in terms of BOD and SS, exhibits as high standards as the so-called '20/30 Royal Commission standard' for safe discharge. However, free ammonia $\left(\mathrm{NH}_{3}\right)$ concentration is much higher than maximum level allowed $\left(<5.0 \mathrm{mg} \mathrm{l}^{-1}\right)$ in order to protect fish from toxicity.

\subsubsection{Salinity}

Tobruk STP's effluent is of a slight salinity $\left(707 \mu \mathrm{s} \mathrm{cm}^{-1}\right)$ and thus it is suitable for the production of most vegetables and fruits (Lazarova and Bahri, 2005). However, it is noteworthy to mention that electrical conductivities presented in Table 2 were measured in January and August at 17.9 and $29.7 C^{\circ}$ respectively. According to Mara (2003), conductivity varies greatly with temperature.

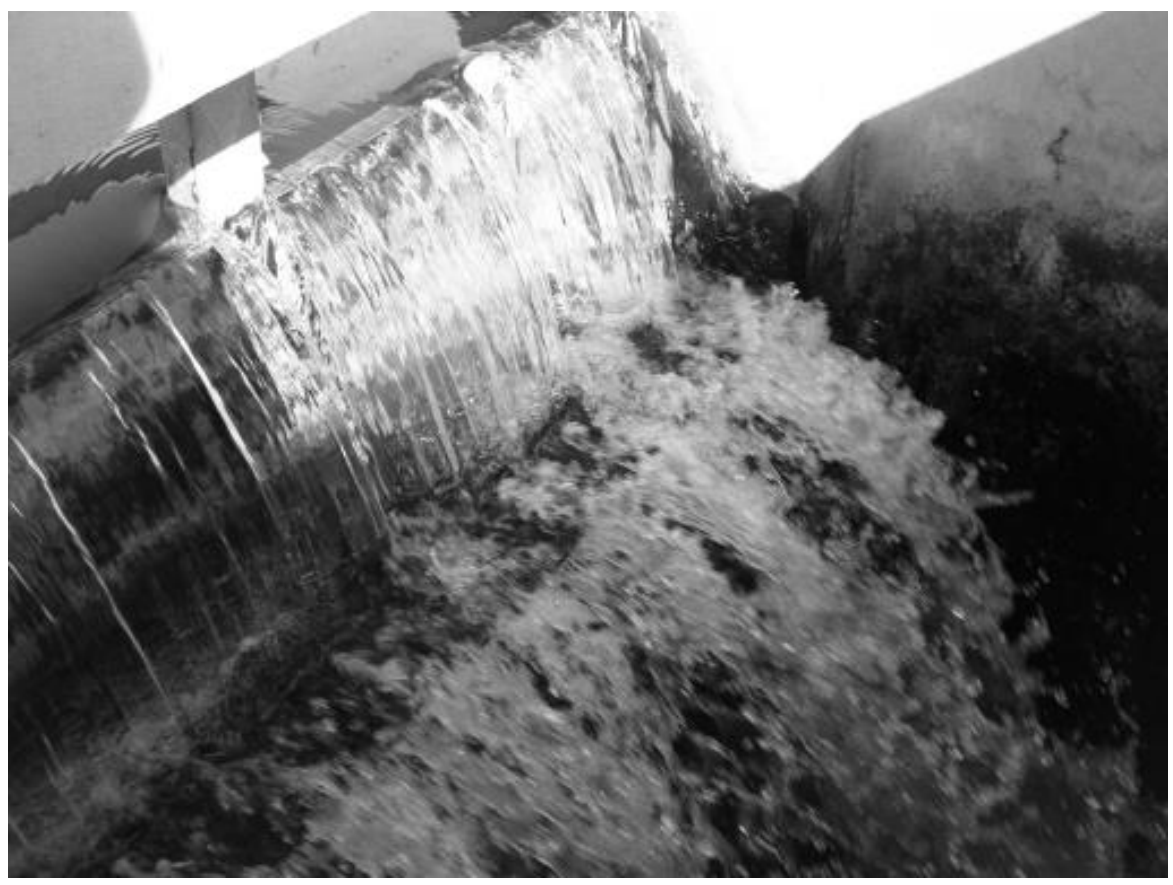

Figure 4. A photo of the treated effluent (Photo. by; Abdulla, 2012)

Substituting $\mathrm{Ca}^{+}, \mathrm{Mg}^{2+}$ and $\mathrm{Na}^{+}$values obtained from Eq. (3), (4) and (5) in Eq. (2), SAR $\approx 2.0$. This value of sodium adsorption ration does not impose restrictions on the use of the effluent for irrigation (Mara, 2003; Lazarova and Bahri, 2005). 


\subsubsection{Specific ion toxicity}

According to Ayers and Westcot (1985), the levels of chloride and sodium presented in Table 2 have, no to slight, degree of restriction on the treated effluent for irrigation.

In arid and semi-arid regions, due to climatic conditions, such as high evapotranspiration rates, high concentrations of sodium and chloride can occur in treated wastewater (Metcalf and Eddy, 2003). Nonetheless, with appropriate irrigation practices and management, detrimental effects of these elements can be reduced significantly, imposing no limitations for reuse (FAO, 2003).

\subsubsection{Trace elements and heavy metals}

It was the intent of this work to review the levels of some selected trace elements that might be present in the treated effluent, but the lack of well-equipped laboratories devoted to sophisticated analyses has hindered this step. However, heavy metals in the treated effluent are unlikely to appear in concentrations higher than permissible levels. This assumption can be justified by the following points:

- Tobruk is not an industrialised region and the sewage treatment plant receives only municipal wastewater from a separate sewerage collection system, i.e. urban stormwater is not involved. Heavy metals, unless excessively added to the sewage by industrial discharges, exhibit concentrations in treated wastewater that are usually lower than maximum limits for irrigation water (FAO, 1985 cited in Abu Madi, 2004).

- Heavy metals in reclaimed water that received at least secondary treatment (which is provided by Tobruk's STP) are generally within acceptable levels for most uses (Metcalf and Eddy, 2007).

- The municipal effluents exhibit low concentrations of heavy metals and trace elements, as a rule, and do not represent a major problem in water reuse projects for irrigation (Lazarova and Bahri, 2005).

- Results from large-scale reuse schemes in developing countries have shown that heavy metal contaminations have not exceeded tolerance levels after many years (Siebe, 1995; Haruvy, 1997; Hussain and Al-Sati, 1999 cited in Abu Madi, 2004).

- heavy metals detected in crops irrigated with domestic wastewater in India has been found to be lower than permissible levels despite the wastewater having been used for irrigation at the same site for nearly 30 years (Yadav et al., 2002 cited in Mara, 2003).

\subsubsection{Nutrients}

Total nitrogen - that is the sum of organic- $\mathrm{N}$, ammonia, nitrite and nitrate requires monitoring and sampling frequency in agricultural reuse systems. The determination of organic- $\mathrm{N}$ entails analytical methods, such as Kjeldahl technique, which is not routinely available in MENA region, and therefore ammonical nitrogen is used in the guidelines for agricultural irrigation with treated wastewater. For instance, guidelines in Jordan limit the concentrations of nitrate- $\mathrm{N}$ and ammonia- $\mathrm{N}$ to $50 \mathrm{mg} \mathrm{l}^{-1}$ (Abu Madi, 2004). Nutrients in Tobruk's STP effluent (Table 2) are lower than permissible levels, and hence they are not of concern.

\subsection{Public Acceptance}

The surveyed people were asked if they were willing to buy and eat crops irrigated with reclaimed wastewater. The results obtained are summarised in Figure 5.

Surprisingly, the less educated people have shown slightly higher positive attitudes than highly educated ones. They, i.e. who have shown their acceptance, mention that there are some countries in the region that use raw domestic wastewater for agricultural irrigation, and thus they believe that treated effluent must be much safer.

Some participants wrongly argued that Islam prohibits the use of treated wastewater for food crops irrigation. However, a 'fatwa' (an authoritative religious ruling) issued in 1978 by the Leading Council of Islamic Scholars of Saudi Arabia stated that treated wastewaters were Islamically 'pure' (Abderrahman, 
2001 cited in Mara, 2003) which means it is permissible for crop production and landscape irrigation This, as the population of the region are $100 \%$ Muslims, provides a powerful incentive for the planning of reuse programmes.

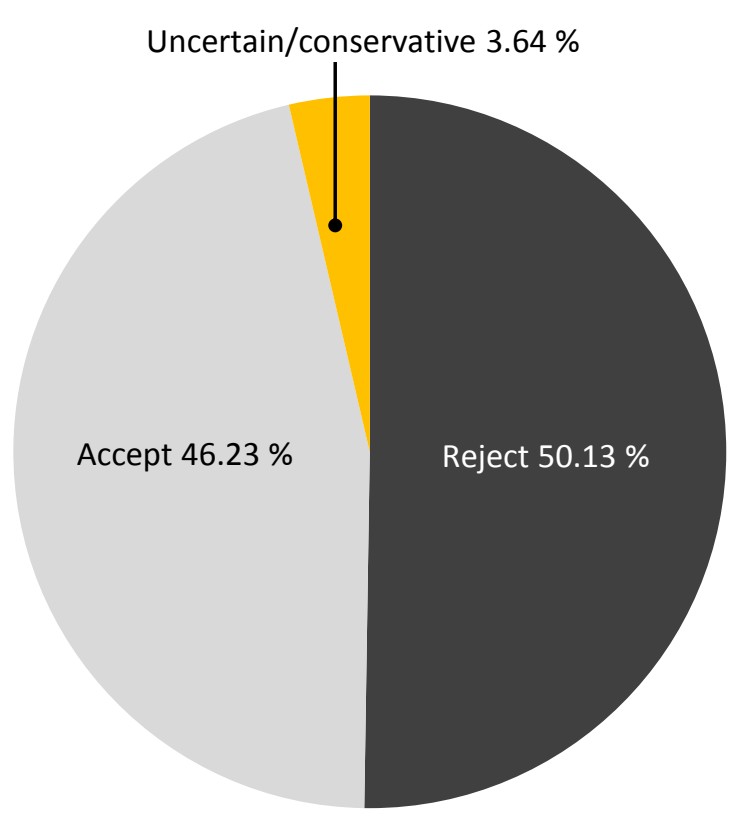

Figure 5. Public attitude toward the use of reclaimed water for irrigation of food crops

During the conducting of the survey, we remained neutral and did not attempt to predispose the surveyed people to have a particular attitude. Nevertheless, when the issue was raised in informal discussions and meetings, some people have switched their attitudes in favour of acceptance.

People who are conservative or uncertain, have concerns about the compliance of reuse schemes plant operators, farmers, etc., with the reclaimed water quality regulations. Their concerns and fears can be interpreted as a 'matter of trust'.

\section{Conclusions and recommendations}

It can be concluded that the treated effluent of Tobruk's sewage treatment plant is suitable for agricultural irrigation as most of the water quality parameters do not exceed the maximum contaminant levels allowed by standards provided in WHO and the MENA countries guidelines of the reuse of wastewater for agricultural irrigation. Moreover, Shuval et al. (1986) in their extensive critical appraisal of realistic epidemiological evidence for health effects of wastewater reuse for crop irrigation concluded that irrigation with treated wastewater does not cause any excess prevalence of Ascaris infection among crop consumers (Mara, 2003).

In addition to its conformity with the international and regional guidelines for treated wastewater use for agriculture, the effluent exhibits (in terms of BOD and SS) as high standards as the so-called '20/30 Royal Commission standard' for safe discharge. However, free ammonia $\left(\mathrm{NH}_{3}\right)$ concentration is much higher than maximum level allowed $\left(<5.0 \mathrm{mg} \mathrm{l}^{-1}\right)$ in order to protect fish from toxicity.

Farms and arable lands are a few hundred meters to 7000 meters from the sewage treatment plant, distances that can make the transport of reclaimed water feasible at reasonable cost.

Although the conventional treatment plant in Tobruk is technologically capable of producing reclaimed water that is suitable for agricultural irrigation, waste stabilisation ponds effluents should be considered for reuse by municipal authorities because they, i.e., waste stabilisation ponds are preferable to 
conventional wastewater treatment systems for irrigation in warm climates, particularly developing countries. According to Shuval and Fattal (1996), John (2000) and Mara (2003), waste stabilisation ponds are characterised by simplicity of construction, operation and maintenance, reliable, higher efficiency in removing pathogens, and yield effluents of good biological quality and rich in nutrients. The major concern over waste stabilisation ponds is the land cost. However, fortunately, land areas in Tobruk are still available at reasonable cost.

Indeed, the lack of knowledge and expertise in this field can be the primary drawbacks impeding the implementation of reuse schemes in Tobruk in the near future. Therefore, a pilot-reuse scheme is highly recommended for planning and designing purposes. This is particularly important now since the environmental authorities are not efficient at the present time.

Due to transparency issues, coupled with the lack of reliable data, cost estimation has not been included in this study.

\section{Acknowledgment}

Sincere thanks to Engineer Jaballa Abdurrahman (Manager of Tobruk's STP) and his colleagues for allowing the access to the STP, permission for taking photos, information and data. Also, many thanks to Dr. Ebtissaam and Hussam for their help in conducting the survey of public perception.

\section{References}

Abu-Madi M.O.R. (2004), Incentive Systems for Wastewater Treatment and Reuse in Irrigated Agriculture in the MENA Region: Evidence from Jordan and Tunisia, Taylor \& Francis Group plc, London.

Alghariani S.A., 2008. Reducing Agricultural Water Demand in Libya Through Improving Water use Efficiency and Cropwater Productivity. AARINENA Water Use Efficiency Network: Proceedings of the Expert Consultation Meeting, 26-27 November 2006, Aleppo, Syria, p.118 [Online WWW], available URL: https://apps.icarda.org/wsInternet/wsInternet.asmx/DownloadFileToLocal?filePath=Research_publications_a rchive/Water/AARINENA.pdf\&fileName=AARINENA.pdf [accessed 25.December 2012]

Al-Jasser A.O. (2010), Saudi wastewater reuse standards for agricultural irrigation: Riyadh treatment plants effluent compliance, Journal of King Saud University - Engineering Sciences, 23(1), 1-8.

Arundel John (2000), Sewage and Industrial Effluent Treatment, Second edition, Blackwell Science Ltd, Cornwall.

EPA Victoria. (2002) Disinfection of Treated Wastewater. EPA Victoria, Victoria. Publication No. 730

FAO, Food and Agriculture Organization of the United Nations (2000) User's Manual for Irrigation with Treated Wastewater. Cairo: FAO Regional Office for the Near East, Egypt. [Online WWW], available URL: https://www.ftp.fao.org/docrep/fao/008/y5009e/y5009e00.pdf [accessed 19 January 2013].

Lazarova V. and Bahri A. (2005), Water Reuse for Irrigation: Agriculture, Landscapes, and Turf Grass. USA: CRC.

Mara D. (2003), Domestic Wastewater Treatment in Developing Countries, Press, Trowbridge, Cromwell.

Metcalf and Eddy, Inc. (2003) Wastewater Engineering Treatment, Treatment and Reuse, Fourth Edition, McGrawHill, New York.

Metcalf and Eddy, Inc. (2007) Water Reuse: issues, technologies, and applications. McGraw-Hill, New York.

Misstear B., Banks D. and Clark L. (2006), Water Wells and Boreholes, John Wiley \& Sons Ltd, Chichester.

Pereira L.S., Cordery I. and Iacovides I. (2009), Coping with Water Scarcity; Addressing the Challenges. E-book: Springer.

Shuval H.I. and Fattal B. (1996), Control of pathogenic microorganisms in wastewater recycling and reuse in agriculture. In: Mara, D., Mara and Horan, N. (2003), Handbook of water and wastewater microbiology. Elsevier. Ch. 15, London.

Smith P.G. and Scott S.J. (2005), Dictionary of Water and Waste Management Second Edition, IWA Publishing, London.

Younger P.L. (2007), Groundwater in the Environment: an introduction, Blackwell Publishing, UK. 


\section{Nomenclatures}

$\mathrm{mg} \mathrm{l}^{-1}$ : Milligrams per litre

$\mathbf{m}^{3}$ : Cubic meters

pH: The power of hydrogen ion.

BOD: Biochemical oxygen demand $\left(\mathrm{mg} \mathrm{l}^{-1}\right)$

COD: Chemical oxygen demand $\left(\mathrm{mg} \mathrm{l}^{-1}\right)$

ss, MLSS: Mixed liquor suspended solids $\left(\mathrm{mg} \mathrm{l}^{-1}\right)$

SAR: Sodium adsorption ratio (dimensionless)

Acronyms \& abbreviations

MENA: The Middle East and North Africa region

STP: Sewage Treatment Plant

WHO: World Health Organization 